\title{
Corporate Social/Environmental Responsibility and Value Creation: Reflections on a Modern Business Management Paradigm
}

http://doi.org/10.21272/bel.4(4).123-131.2020

Marco Taliento, ORCID: https://orcid.org/0000-0002-9291-4736

$\mathrm{PhD}$, Full Professor of Business Economics, Accounting and Corporate Valuation, University of Foggia, Department of Economics, Foggia, Italy

Antonio Netti, ORCID: https://orcid.org/0000-0001-8424-6670

$\mathrm{PhD}$, Lecturer of Business Administration, University of Foggia, Department of Laws, Foggia, Italy

\begin{abstract}
The present article deals with a new, modern business management paradigm founded on both the social and the environmental responsibility of firms intended as powerful instruments to match the issue of sustainability with corporate performance and value creation (thus evolving from the classical shareholder value to a new, more comprehensive, shared value view). The Directive 2013/34/EU required the disclosure of large enterprises and groups' non-financial and diversity information. At the same time, a growing number of proactive companies which behave with real initiatives more compliant to the so-called Stakeholder Theory have become quite familiar to produce CSR and sustainability reports periodically to share with the community their relevant responsibility actions and achievements (3 P results or triple-bottom-line performance, as for profit, people, planet). Such a complex, behavioral and informative approach follows the corporate governance setting and management strategy within the ethical domain (business ethics). In this perspective, we conduct a systematic research study on the economic literature that showed a focus on the possible relation between the responsible behavior/information and the economic/financial performance of firms, analyzing both the empirical findings and theoretical works significantly investigating the effect of sustainability indicators on financial and market results. According to the general studies, socially responsible policies can produce a positive impact on company performance by many advantages such as the reduction of operating costs and financial risks, an increase of efficiency and competitiveness, the improvement of the company's reputation and a related increase in consumer confidence; despite preceding studies pointed out that CSR investments and responsibility policies (representing the result of an agency conflict between managers and shareholders) would generate just an increase in costs and a consequent decline in the performance of companies. The consideration of the ESG (environmental, social and governance) - which completes the CSR issue - and its new goals in the long run, even as a component of the holistic enterprise risk management system, finally enables us to reinterpret the fundamental competitive advantage of firms in a sustainability key. In particular, the environmental, social and governance extra-performance over the industry may show to be more 'valuerelevant' than the absolute ESG ratings itself. In conclusion, the social, environmental and governance responsibilities (to all stakeholders) are building a set of dynamic capabilities and actions which reveal a new competitive (X) Factor of the modern corporation.
\end{abstract}

Keywords: CSR, Environmental-Social-Governance, Economic Performance, Value Creation; Stakeholder Theory, Sustainability Disclosure.

JEL Classification: M1, M14, M4, G3.

\section{(i)}

This work is licensed under a Creative Commons Attribution 4.0 International License

Cite as: Taliento, M., Netti, A. (2020). Corporate Social/Environmental Responsibility and Value Creation: Reflections on a Modern Business Management Paradigm. Business Ethics and Leadership, 4(4), 123-131. http://doi.org/10.21272/bel.4(4).123-131.2020.

(C) The Authors, 2020. This article is published with open access at Sumy State University.

\section{Introduction}

In recent years, the theories that see the satisfaction of the needs of all stakeholders as a necessary condition for sustainable value creation and, more in general, the theme of Corporate Social Responsibility (CSR), have 
assumed great importance in economic and business studies and professional practice (Abbott \& Monsen, 1979; Freeman, 1994; Donaldson and Preston, 1995; Clarkson, 1995; Carroll, 1999; Crane et al., 2017). Several authors argue that social and environmental responsibility can be a significant benefit to competitive enterprise (Hart, 1995). Some empirical research demonstrated that social and responsible behaviors have a positive effect on company performance (Waddock and Graves, 1997; Van Beurden and Gossling, 2008; Kim and Kim, 2014; Kim et al., 2018), generating important advantages for companies, including the reduction of operating costs and financial risks, the improvement of efficiency and competitiveness and the growth of company's reputation and consumer confidence (Barney, 1991; Porter 1991; Hammond and Slocum, 1996; Porter and Kramer, 2006; Bird et al., 2007; Weber, 2008; Dahlsrud, 2008; Flammer, 2015). Instead, other authors pointed out that social responsibility policies can generate an increase in costs and a consequent decline in the performance of companies (Friedman, 1962, 1970). In this perspective, CSR investments can represent an agency conflict between managers and shareholders (Jensen and Meckling, 1976). The former, to establish lasting partnerships and trustees with stakeholders, implement sustainability policies that reduce the shareholders' returns (Flammer, 2015). It, however, does not mean that the company should not enforce sustainability policies, because the managers find it essential to promote such behaviors to maintain stable relationships with stakeholders (Moser and Martin, 2012), and because the shareholders may require the implementation of CSR policies for ethical or moral reasons while being aware of generating lower financial performance (Mackey et al., 2007). Moreover, companies might decide to support commercial purposes, through the costs related to implementing these policies (Moon, 2002), or to increase their image on the market (Caulkin, 2002).

In this perspective, the communication strategy and socio-environmental policies may be fundamental for the company's value creation. It is confirmed by the recent issuing of frameworks, standards, and guidelines for the preparation of socio-environmental reports in the professional field and the growing attention to these issues by international legislators. This work aims to provide a theoretical framework on possible relations between adopting responsible policies and company value creation. More specifically, through the analysis of some of the main doctrinal contributions on the subject, we point out that the achievement of sustainable results and, more generally, a value creation oriented to the long term cannot disregard from the implementation of management models based on behavioral responsibility, as well as satisfying the expectations of the different categories of stakeholders (Cooper, 2017).

\section{The Corporate Responsibility: A New Strategic Approach to Business Management (Stakeholders Oriented)}

The growing interest in corporate social responsibility and sustainable development has determined a profound rethinking of the corporate governance process, promoting the adoption of a new approach to the strategic model, not focused anymore exclusively on profit maximization, but that combines the achievement of financial performance with the preservation of the environment, social cohesion and more balanced and fair distribution of value. These changes and developments have been favored by the spread of authoritative guiding principles and prominent standards (EMAS, Global Compact of United Nations, Guiding Principles on Business and Human Rights, ISO 26000, GRI - Global Reporting Initiative, PRI, International Integrated Reporting Council ("the IIRC")), and the proliferation of corporate ethical codes, which have promoted the adoption of sustainable management practices. In turn, they are mainly characterized by the importance of stakeholders' relations. With specific reference to the most recent ESG perspective (Environmental-SocialGovernance), the London Stock Exchange Group (and Borsa Italiana S.p.A.) in 2017 have issued an interesting guide featuring some recommendations on voluntary and non-financial information to be integrated into the listed company disclosure. This new strategic-management approach adoption has determined some important impacts on the financial reporting, with the introduction of the "Integrated Reporting" that includes financial performance and the social, environmental and economic context in a single document, within which the company operates. In this perspective, the evolution of European company law (Directive No. 2014/95/EU) has introduced new information tools, in some cases as mandatory and in other cases as optional terms, about socially responsible behaviors and, more generally, on sustainability disclosure. The rule, in particular, concerns the enterprises or the largest groups, involving the processing and the disclosure of non-financial information by appropriate means declaration/report (NFI: Non-financial Information) on the business model, on strategic policies, sustainability risks and the so-called Key Performance Indicators (KPIs).

The new reporting model allows the various corporate stakeholders to have feedback of companies' social (private welfare, social practices and benefits for employees, respect for the law, working standards, etc.) and environmental commitment (renewable energy, efficiency, energy, recycling and combating waste, etc.); 
moreover, it promotes an adequate representation of management quality (procedures and good administrative rules and control, effective role of ownership and board monitoring functions, mitigation of internal conflicts, etc.), beyond the traditional economic and financial information. The main doctrinal guidelines on corporate social responsibility and, more particularly, on the role it plays in the company value creation are set out below. The fundamental stakeholder theory (Mitchell et al., 1997; Ruf et al., 2001) argues that companies to create a sustainable value in the long term must consider all parties interests which, directly or indirectly, are involved in the company (Freeman, 1984). In this perspective, companies have necessarily to operate in the interest of all categories of subjects that interact within the markets and institutions because the dissatisfaction of any group of stakeholders may potentially lead to the deterioration of assets and liabilities, financial position and the economic performance of the company, even endangering its existence (Clarkson, 1995). As long as the stakeholder theory focuses on the relationship between the company and its stakeholders, arguing that the same should all (equally) be considered and satisfied to create sustainable value in the long term (Freeman et al., 2010), Corporate Social Responsibility (CSR) theory instead finds the company in another perspective. The CSR, in essence, can be defined as the responsibility towards the communities or "society in general" (in terms of education promotion, health care, environmental conditions, charity, ethics of behavior, etc.) or, in other words, the company's commitment to fair behavior, aware of economic, social and environmental consequences of such behavior (Freeman et al., 2017).

In this context, some authors have recently theorized a value creation model that focuses on the connections between social and economic progress, named Corporate Shared Value (CSV) (Porter and Kramer, 2011). This model provides a new strategic approach in which companies create value through the benefits produced in the social environment. In other words, the shared value includes policies and practices that increase the company's value and competitiveness beyond the traditional shareholder value, improving economic and social conditions in the communities where the company works. In short, this approach represents a different way of spreading wealth through the creation of social benefits, in which competitiveness and profit are driven by the satisfaction of the stakeholders and general community needs.

Another essential thread is known - as said - by the acronym of ESG (Environmental, Social and Governance). Although such expression is used in different contexts and does have an ambiguous definition (Bassen and Kovács, 2008), it is usually used to indicate environmental, social and governance factors by integrating the traditional economic and financial parameters to allow assessing the sustainability of investments in a long period (Bourghelle et al., 2009; Van Duuren et al., 2016). It should be noted that for the UN Principles for Responsible Investment (PRI), Environmental, Social and Governance Factors refer to three distinct but related areas of expanded 'social sensitivity' and ethics. The first is the environment and includes climate changes, greenhouse gas emissions, exploitation of resources, waste, pollution and deforestation. The second includes working conditions, health and safety, employee relations and diversity. The third concerns corporate governance practices, including management policies remuneration, board composition, audit procedures and management and company behavior regarding respect for the laws and ethical principles. Moreover, Agenda 2030 for sustainable development - approved in 2015 - represents a significant opportunity for companies to propose solutions to current challenges (see SDG no. 8 and 10 on balanced and sustainable economic growth characterized by dignified work, or the fight against inequalities). In this respect, the interesting survey Accenture-UN Global Compact (2016 “Agenda 2030: A Window of Opportunity") recently involved over 1,000 companies, executive directors operating in more than 100 countries and over 25 industrial sectors, to understand the general point of view of the business community about the "Agenda". The survey above pointed out that company system is considered, by half of the CEOs surveyed, the main tool for the implementation of UN Sustainable Development Goals (SDGs); that is a wide range of orientation to partnerships and actions towards the community and cooperation with the institutions; the ability to document sustainability results, including the ones towards the financial community, shall be deemed of fundamental importance. Own in this respect, it is considered necessary the development of new standardized metrics for measuring the impacts and additional indicators to communicate the contribution to the pursuit of sustainability goals.

\section{Interrelations Between a Social/Environmental Responsibility-Oriented Management and Value Creation: Some Recent Evidence}

Several studies have recently also examined the possible impacts of adopting ethical responsibility policies on company performance (effectiveness), often with mixed results. According to the prevailing research literature, socially responsible policies produce a positive impact on company performance by determining many advantages such as the reduction of operating costs and financial risks, efficiency and competitiveness, the improvement of the company's reputation and a related increase in confidence by the consumer (Barney, 1991; 
Porter, 1991; Hart, 1995; Hammond \& Slocum, 1996; Neville et al., 2005; Porter \& Kramer, 2006, 2011; Bird et al., 2007; Weber, 2008; Flammer, 2015). In the same perspective, it was also highlighted that companies that adopt irresponsible or illegal behaviors could lead to disadvantages for shareholders; to increase the company's value (Damodaran, 2016), therefore, it is required to behave socially responsible and to meet the expectations of all stakeholders (Freeman, 1984; 1994; 2010).

Instead, further research has indicated a negative correlation between the two variables mentioned above, arguing that social responsibility policies shall determine an increase in costs and a consequent contraction of business results (Friedman, 1962, 1970, 2007) exclusively. However, not all studies agree on the type of relationship between CSR and company performance policies. Some research, for example, argue that the effects of CSR on CFP (Corporate financial performance) may affect negatively in the short term and positively in a long time; so that investments in socially responsible behavior may result in benefits for shareholders, who would therefore need long-term planning (Mcguire et al., 1988; Barnett \& Salomon, 2006). Instead, other analyses identify an inverse relationship describing positive effects in the short term and negative impacts in the medium-long term (Wang et al., 2008). For completeness, we also have to mention the studies that postulate a substantial insignificant relationship between CSR and business-generated results (Griffin \& Mahon, 1997; Griffin, 2000). According to this guideline, the number of factors that may affect the relationship with the business results is so high that it appears impossible or, not easy to isolate (and demonstrate) a unique link among the variable restatements (Ullmann, 1985; Mcwilliams \& Siegel, 2001).

In recent years, many authors have tried to verify if there is a direct causal relationship between the newer ESG issue and the financial performance of firms (Peiró-Signes et al., 2013; Friede et al., 2015; Shaukat et al., 2016): despite the efforts made, the above studies have not been able to demonstrate, unambiguously, whether the ESG factors can influence company financial results positively or negatively (van Beurden and Gössling, 2008; Hoepner and Mcmillan, 2009; Galbreath, 2013; Lokuwaduge and Heenetigala, 2017). Eccles et al. (2013) argue that only the more "innovative" companies that are more competent to combine and integrate innovation in the business model with the ESG perspective can realize a virtuous development path reaching more easily higher financial performance. From the analysis carried out on more than three thousand organizations (from 2002 to 2011), the authors above showed how in the absence of innovations, substantial financial performance of a company may even get worse in correspondence to a better performance in ESG perspective (see Fig. 1 for the frontier EG performance / financial performance).

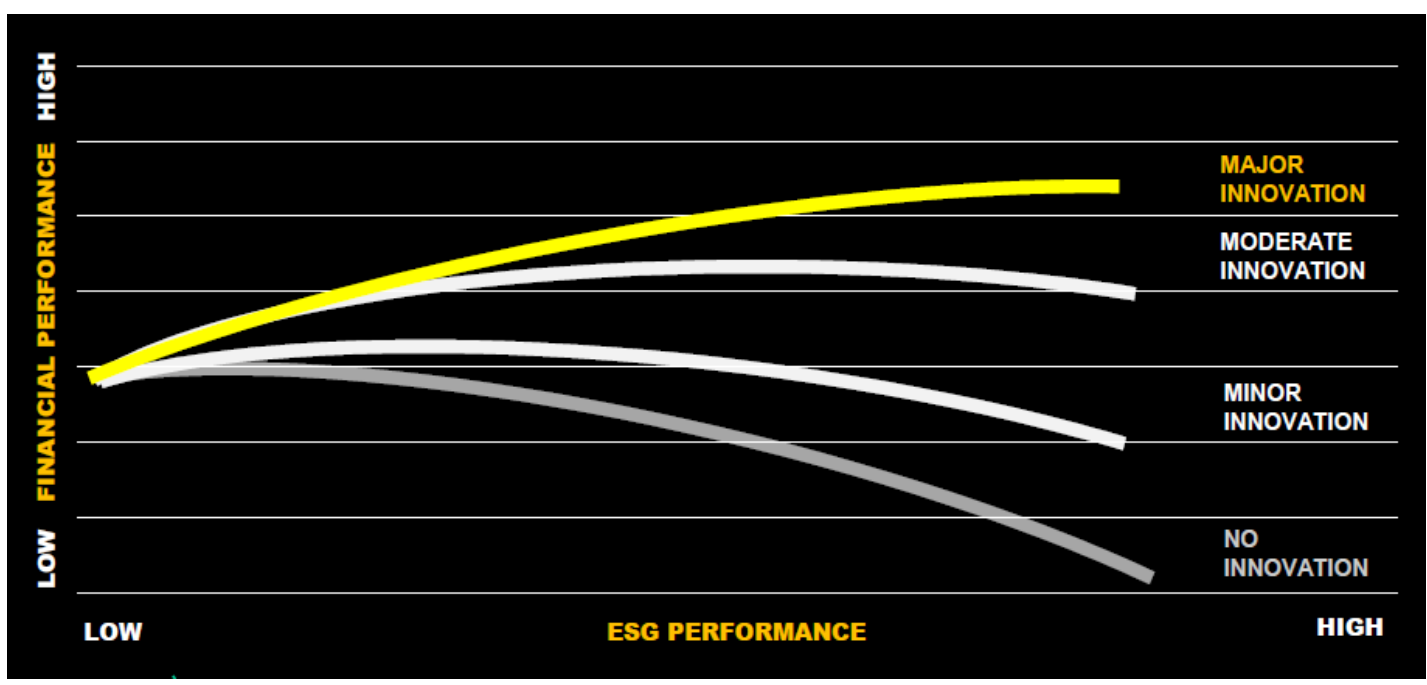

Figure 1. The Frontier EG Performance/Financial Performance of Companies

Source: Adapted from Eccles et al., 2013

Consequently, to set up a sustainable strategy for the company in the long term, the main stakeholders' requests should be seriously considered and never neglected. The positive effect - represented graphically by a "twodimensional" frontier of performance (Fig. 1) - is conditioned, in a significant way, by knowing how to invent new products, processes and business models. In fact, in the absence of substantial innovation, Eccles et al. (2013) found that firms' financial performance declines as their environmental, social, and governance (ESG) performance improves. To simultaneously improve both kinds of performance, companies need to invent new products, processes, and business models. Other authors, instead, have demonstrated that the assessment of ESG factors allows better identification of a company's risks and opportunities, thereby fostering advanced technologies, risk management processes and the conditions that affect company results (Bassen and Kovács, 2008). 
Besides, ESG performance may be interpreted as a measure of the management quality: it may represent the company's ability to address long-term trends to preserve and ensure its competitive advantage (Ling et al., 2007). Recent research on the specific theme of ESG (Taliento et al., 2019) provides further analysis of the operative, socio-environmental and governance "dimensions" to prove the possible influence of sustainability performance indicators on the company's financial performance. Therefore, it can be included in the CSR/performance studies considering the Stakeholders Theory framework and is consistent with the Shared Value Theory. As mentioned above, today, new information is required on the social and responsible behavior or, in other words, the sustainability disclosure (e.g., Agenda 2030). In such context, it has been carried out, with partial completion of the literature and in harmony with existing practice, an empirical analysis on the relationship between financial and non-financial company results, also using an advancing and innovative methodology in this specific field (Structural Equation Modeling: PLS/SEM methodology).

In particular, a sample was selected as representative of the European companies in Italy, France, Spain, Germany, Belgium listed on main stock market indices (such as FTSE-MIB, CAC, IBEX, DAX, BEL), to investigate - for the period 2014-2017 - the existence of a possible value "relevance" of the non-financial (ESG) performance. As a result, the ESG dimension appeared to impact the financial performance not so much on the absolute scores the companies were assigned, based on their responsibility/sustainability profile and behavior, as instead in their "positioning" in the ESG framework. It means in the "distance" from the average values of the sector to which it belongs (excess or ESG over the industry, called "extra-ESG advantage", expressing a sort of economic advantage from sustainability or, better, a 'goodwill' from environmental, social and governance extra-performance over the industry). The following figure (Fig. 2) illustrates that results obtained from a statistical/econometric analysis (above mentioned).

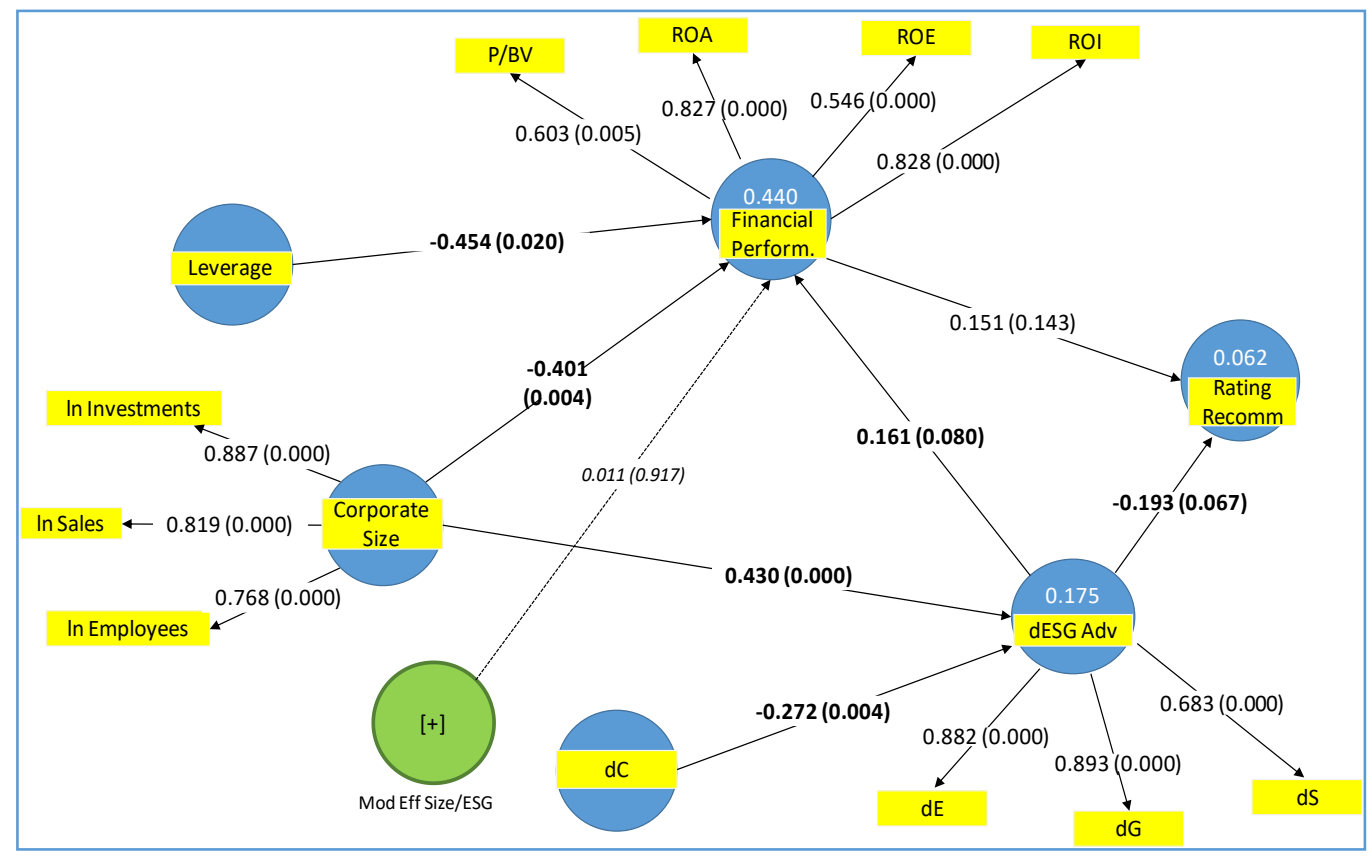

Figure 2. Path Diagram: The Effect of Extra ESG Rating over Industry on Financial Performance

Source: Taliento et al., 2019

The results confirm - coeteris paribus - that the attention to the social and environmental issues, combined with the respect for the rules and good governance, prove to be a concrete dimension and condition able together with the control of corporate size (significant background factor heralding greater slack resources) to facilitate the production of higher yield/sustainable value lato sensu, thus revising the notion of competitive advantage in terms of sustainability goals. The social, environmental and governance responsibility (to all stakeholders) appear to be undoubtedly critical and growingly material as a new competitive factor of the modern firm. The variable "dESG Adv" is the extra ESG advantage of firms over their industry mean values.

\section{Conclusion}

As known, the Directive n. 2014/95/EU, the subsequent norms and guidelines (EUG) have recently promoted a marked improvement in the sustainability disclosure, especially for larger companies or groups required to report the non-financial information properly. Indeed, a greater firm size implies an obligation to inform the non-financial results, which, in turn, represents an incentive (especially for prominent companies) to better 
operate on the responsible basis with real initiatives able to produce a positive and wide outcome. Such aspects are subject to growing attention (and an innovative disclosure) that is more and more addressed to the financial investors and other stakeholders. Hence, companies are motivated to responsibly invest and ethically manage the business also to gain legitimacy and reputation (even in line with the UN Agenda 2030). That said, the article showed how the new ESG issue can complete the CSR issue, and how they both can create a shared value. The $\mathrm{G}$ inclusion (governance dimension, in addition to the previous limited focus concerning the $\mathrm{E} \& \mathrm{~S}$ hendiadys performance) appears important since the recent ESG triad worldwide spread has raised the attention and interest of investors/stakeholders. Moreover, it is known that the characteristics of $\mathrm{G}$ (governance dimension, which in turn expresses the traditional "room" of generation and management of economic value) constitute the administrative micro-environment in which $\mathrm{E}$ (environmental) and $\mathrm{S}$ (social) policies are formed and proliferate, finally implemented by directors and managers. Today, in this regard, even the CoSO (2018) emphasizes the impact of environmental, social and governance (ESG) factors as well as the opportunity to implement such elements in the risk management strategies of companies (as new risk factors).

In other words, the social, environmental and governance responsibilities (to all stakeholders) act as a set of dynamic capabilities that expresses a new competitive (X) Factor of the modern corporation. The fact that many companies are stipulating such growing responsibilities next to the core business responsibilities means that they are willing to act also in the interest of the stakeholders who are mainly involved and conditioned by the corporate choices (employees, customers, communities, suppliers, and financiers, retained equally important). As a result, making economic performance and serving society with environmental respect can move in the same direction when a firm incorporates the societal or welfare interests into its business purpose, strategy and operations (within the ethical domain).

In the European context scrutinized in Taliento et al. (2019), a performing ESG engagement (comparatively considered to the competitors' commitment) confirms to be a (market $\&$ accounting) value relevant condition associated with the production of greater economic-financial returns. On the one hand, such effect can be achieved by the market and financial investors recognition, judgment, appreciation and support, and, on the other hand, by total incomes from revenues and sales in such amount to recover the greater investments and costs necessary to ensure the intensity, proficiency and efficacy of the company's responsibility policy and behavior. In details, a general or generic commitment in ESG is not enough; instead, an improvement effect on corporate profitability can spring from a comparative extra-ESG performance over the industry sector (the extra-ESG reflects a better attitude to competitiveness concerning the industry or competitors, due to an increased efficiency along with higher corporate reputation, consumer confidence, and more stable relationships; it also may reflect greater confidence in human capital boosting labor productivity: this will attract the sector's stakeholders with a greater propensity to purchase goods or services and to financial investments, supporting the growth of the economic performance).

In particular, the previous study (Fig. 2) found a positive path coefficient (equal to $+0,161$ ) from extra-ESG to Financial/Market Performance (in contrast to the cost-concerned school which postulates that investing in ESG activities, in entailing time- and resource-consuming efforts, increases costs putting businesses in a situation of economic disadvantage; on the other hand, the positive finding is remarkably similar to the Orlitzky et al. (2001)'s corrected average correlation coefficient between the corporate social performance and the financial performance (equal to 0,150), as well as to the Margolis et al. (2009)'s reported coefficient (approximately 0,13) and also to the more recent Friede et al. (2015)'s weighted correlation (of almost 0,120); at the same time, the extra-ESG advantage is associated: negatively (coefficient: -0,272), with controversies indicators; positively, with the firm size indicator (coefficient: $+0,430$, according to the slack resources theory); positively, with analysts' recommendations to "buy" (reverse scale).

The attention for the social and the defense of the environment, both coupled with a sound corporate governance structure and functioning, may represent a concrete condition that facilitates the value creation in a complete sense. More generally, positive effects would likely be even higher by encapsulating the ESG in the IR (Integrated Reporting) (Mervelskemper et al., 2017; Hoang, 2018). In conclusion, in the light of the above research literature - mainly as discussed ex multis in Taliento et al. (2019), and other scholars, it can reasonably be argued that the traditional model management is based exclusively on profit maximization for shareholders represents a largely outdated paradigm. The creation of long-term, stable value in a broad sense, capable of meeting all stakeholders' expectations, should be guided by an awareness of social responsibility and sustainability issues. Such approach denotes a new frontier in the company management and for the business consulting and whole macro-economic context as well. 
Author Contributions. Conceptualization, Marco Taliento; literature review, Marco Taliento and Antonio Netti; methodology, Marco Taliento; formal analysis, Antonio Netti; writing, original draft, Marco Taliento; writing, review and editing, Antonio Netti; project and administration, Marco Taliento and Antonio Netti; supervision, Marco Taliento.

Funding. There is no funding for this research.

\section{References}

1. Abbott, W.F., \& Monsen, R.J. (1979). On the measurement of corporate social responsibility: Self-reported disclosures as a method of measuring corporate social involvement. Academy of Management Journal, 22(3), 501-515. https://doi.org/10.5465/255740.

2. Barnett, M.L., \& Salomon, R.M. (2006). Beyond dichotomy: The curvilinear relationship between social responsibility and financial performance. Strategic Management Journal, 27(11), 1101-1122. https://doi.org/10.1002/smj.557.

3. Barney, J. (1991). Firm resources and sustained competitive advantage. Journal of Management, 17(1), 99-120. https://doi.org/10.1177/014920639101700108.

4. Bassen, A., \& Kovács, A.M. (2008). Environmental, Social and Governance Key Performance-Indicators from a Capital Market Perspective. Zeitschrift für Wirtschafts-und Unternehmensethik. Journal for Business, Economics \& Ethics, 9(2), 182-192. https://doi.org/10.5771/1439-880X-2008-2-182.

5. Bird, R., Hall, A.D., Momentè, F., \& Reggiani, F. (2007). What corporate social responsibility activities are valued by the market? Journal of Business Ethics, 76(2), 189-206. https://doi.org/10.1007/s10551-006-9268-1.

6. Bourghelle, D., Hager, J., \& Louche, C. (2009). The integration of ESG information into investment processes: Toward an emerging collective belief? Working Paper, Vlerick Leuven Gent Management School. Available at: https://ideas.repec.org/p/vlg/vlgwps/2009-26.html.

7. Carroll, A.B. (1999). Corporate social responsibility: Evolution of a definitional construct. Business \& Society, 38(3), 268-295. https://doi.org/10.1177/000765039903800303.

8. Caulkin, S. (2002). Good thinking, bad practice. The Observer, 7. Available at: https://www.theguardian.com/observer.

9. Clarkson, M.E. (1995). A stakeholder framework for analyzing and evaluating corporate social performance. Academy of Management Review, 20(1), 92-117. https://doi.org/10.5465/amr.1995.9503271994.

10.Cooper, S. (2017). Corporate social performance: A stakeholder approach. Taylor \& Francis. https://doi.org/10.4324/9781315259239.

11.CoSO (2018). Enterprise risk management: Applying enterprise risk management to environmental, social and governance-related risks by the Committee of Sponsoring Organizations of the Treadway Commission (CoSO) and the World Business Council for Sustainable Development (WBCSD). Available at: https://www.wbcsd.org/erm.

12.Crane, A., Henriques, I., Husted, B.W., \& Matten, D. (2017). Measuring Corporate Social Responsibility and Impact: Enhancing Quantitative Research Design and Methods in Business and Society Research. Business \& Society, 56(6), 787-795. https://doi.org/10.1177/0007650317713267.

13.Dahlsrud, A. (2008). How corporate social responsibility is defined: an analysis of 37 definitions. Corporate Social Responsibility and Environmental Management, 15(1), 1-13. https://doi.org/10.1002/csr.132.

14.Damodaran, A. (2016). Damodaran on valuation: security analysis for investment and corporate finance (Vol. 324). John Wiley \& Sons, NY. Available at: https://www.wiley.com/en-us.

15.Donaldson, T., \& Preston, L.E. (1995). The stakeholder theory of the corporation: Concepts, evidence, and implications. Academy of Management Review, 20(1), 65-91. https://doi.org/10.5465/amr.1995.9503271992.

16.Eccles, R.G., Serafeim, G., Seth, D., \& Ming, C.C.Y. (2013). The Performance Frontier: Innovating for a Sustainable Strategy Interaction. Harvard Business Review, 91(7), 17-18. Available at: https://hbr.org/2013/05/the-performance-frontier-innovating-for-a-sustainable-strategy.

17.Flammer, C. (2015). Does corporate social responsibility lead to superior financial performance? A regression discontinuity approach. Management Science, 61(11), 2549-2568. https://doi.org/10.1287/mnsc.2014.2038.

18.Freeman, R.E. (1984). Strategic management: A stakeholder perspective. Boston: Pitman, 13. ISBN: 0273019139. Available at: https://research.monash.edu/en/publications/strategic-management-astakeholder-approach. 
19.Freeman, R.E. (1994). The politics of stakeholder theory: Some future directions. Business Ethics quarterly, 409-421. https://doi.org/10.2307/3857340.

20.Freeman, R.E. (2010). Strategic management: A stakeholder approach. Cambridge university press. Available at: https://www.cambridge.org/.

21.Freeman, R.E., \& Dmytriyev, S. (2017). Corporate social responsibility and stakeholder theory: Learning from each other. Symphonya. Emerging Issues in Management, 1, 7-15. https://doi.org/10.4468/2017.1.02freeman.dmytriyev.

22.Frey, M. (2018). Agenda 2030 e ruolo delle imprese [2030 Agenda and the role of businesses]. ImpresaProgetto, 2. Available at: https://www.impresaprogetto.it/editorials/2018-2/frey.

23.Friede, G., Busch, T., \& Bassen, A. (2015). ESG and financial performance: aggregated evidence from more than 2000 empirical studies. Journal of Sustainable Finance \& Investment, 5(4), 210-233. https://doi.org/10.1080/20430795.2015.1118917.

24.Friedman, M. (1962). Capitalism and freedom: With the assistance of Rose D. Friedman. University of Chicago Press. Available at: https://press.uchicago.edu/ucp/books/book/chicago/C/bo18146821.html.

25.Friedman, M. (1970). The social responsibility of the business is to increase its profits. New York Times Magazine, 13. https://doi.org/10.1007/978-3-540-70818-6 14.

26.Friedman, M. (2007). The social responsibility of business is to increase its profits. In Corporate ethics and corporate governance (pp. 173-178). Springer, Berlin, Heidelberg. https://doi.org/10.1007/978-3-540-708186_14.

27.Galbreath, J. (2013). ESG in focus: the Australian evidence. Journal of Business Ethics, 118(3), 529-541. https://doi.org/10.1007/s10551-012-1607-9.

28.Global Reporting Initiative (GRI) Global Sustainability Standards Board (GSSB) (2017). Linking the GRI Standards and the European Directive on non-financial and diversity disclosure. Available at: https://www.globalreporting.org/standards/resource-download-center/linking-gri-standards-and-europeandirective-on-non-financial-and-diversity-disclosure/.

29.Griffin, J.J. (2000). Corporate social performance: Research directions for the 21st century. Business \& Society, 39(4), 479-491. https://doi.org/10.1177/000765030003900407.

30.Griffin, J.J., \& Mahon, J.F. (1997). The corporate social performance and corporate financial performance debate: Twenty-five years of incomparable research. Business \& Society, 36(1), 5-31. https://doi.org/10.1177/000765039703600102.

31.Hammond, S.A., \& Slocum, J.W. (1996). The impact of prior firm financial performance on subsequent corporate reputation. Journal of Business Ethics, 15(2), 159-165. https://doi.org/10.1007/BF00705584.

32.Hart, S.L. (1995). A natural-resource-based view of the firm. Academy of Management Review, 20(4), 986-1014. https://doi.org/10.5465/amr.1995.9512280033.

33.Hoang, T. (2018). The Role of the Integrated Reporting in Raising Awareness of Environmental, Social and Corporate Governance (ESG) Performance. In Stakeholders, Governance and Responsibility (pp. 47-69). Emerald. https://doi.org/10.1108/S2043-052320180000014003.

34.Hoepner, A.G., \& McMillan, D.G. (2009). Research on "responsible investment": An influential literature analysis comprising a rating, characterisation, categorisation and investigation. Characterisation, Categorisation and Investigation https://doi.org/10.2139/ssrn.1454793. August 14, 2009.

35.Jensen, M.C., \& Meckling, W.H. (1976). Theory of the firm: Managerial behavior, agency costs and ownership structure. Journal of Financial Economics, 3(4), 305-360. https://doi.org/10.1016/0304405X(76)90026-X.

36.Kim, M., \& Kim, Y. (2014). Corporate social responsibility and shareholder value of restaurant firms. International Journal of Hospitality Management, 40, 120-129. https://doi.org/10.1016/j.ijhm.2014.03.006.

37.Kim, K.H., Kim, M., \& Qian, C. (2018). Effects of corporate social responsibility on corporate financial performance: A competitive-action perspective. Journal of Management, 44(3), 1097-1118. https://doi.org/10.1177/0149206315602530.

38.Ling, A., Forrest, S., Lynch, M., \& Fox, M. (2007). Global food \& beverages: integrating ESG. Goldman Sachs. Available at: https://www.goldmansachs.com/insights/index.html.

39.Lokuwaduge, C.S.D.S., \& Heenetigala, K. (2017). Integrating environmental, social and governance (ESG) disclosure for a sustainable development: an Australian study. Business Strategy and the Environment, 26(4), 438-450. https://doi.org/10.1002/bse.1927.

40.London Stock Exchange Group (2017). Revealing the full picture. Your guide to ESG reporting - Guidance for issuers on the integration of ESG into investor reporting and communication. February. Available at: https://www.lseg.com/sites/default/files/content/images/Green_Finance/ESG/2018/February/LSEG_ESG _report_January_2018.pdf. 
41.Mackey, A., Mackey, T.B., \& Barney, J.B. (2007). Corporate social responsibility and firm performance: Investor preferences and corporate strategies. Academy of Management Review, 32(3), 817-835. https://doi.org/10.5465/amr.2007.25275676.

42.Margolis, J.D., Elfenbein, H.A., \& Walsh, J.P. (2009). Does it pay to be good and does it matter? A metaanalysis of the relationship between corporate social and financial performance. SSRN Electronic Journal. https://doi.org/10.2139/ssrn.1866371.

43.McGuire, J.B., Sundgren, A., \& Schneeweis, T. (1988). Corporate social responsibility and firm financial performance. Academy of Management Journal, 31(4), 854-872. https://doi.org/10.2307/256342.

44.McWilliams, A., \& Siegel, D. (2001). Corporate social responsibility: A theory of the firm perspective. Academy of Management Review, 26(1), 117-127. https://doi.org/10.5465/amr.2001.4011987.

45.Mervelskemper, L., Streit, D. (2017). Enhancing Market Valuation of ESG Performance: Is Integrated Reporting Keeping its Promise? Business Strategy and the Environment, Wiley Blackwell, 26, 536-549. https://doi.org/10.1002/bse.1935.

46.Mitchell, R.K., Agle, B.R., \& Wood, D.J. (1997). Toward a theory of stakeholder identification and salience: Defining the principle of who and what really counts. Academy of Management Review, 22(4), 853-886. https://doi.org/10.5465/amr.1997.9711022105.

47.Moon, J. (2002). The Social Responsibility of Business and New Governance. Government and Opposition, 37(3), 385-408. https://doi.org/10.1111/1477-7053.00106.

48.Moser, D. V., \& Martin, P. R. (2012). A broader perspective on corporate social responsibility research in accounting. The Accounting Review, 87(3), 797-806. https://doi.org/10.2308/accr-10257.

49. Orlitzky, M. (2001). Does firm size confound the relationship between corporate social performance and firm financial performance? Journal of Business Ethics, 33(2), 167-180. https://doi.org/10.1023/A:1017516826427.

50.Peiró-Signes, A., Segarra-Oña, M., Mondéjar-Jiménez, J., \& Vargas-Vargas, M. (2013). Influence of the environmental, social and corporate governance ratings on the economic performance of companies: An overview. International Journal of Environmental Research, 7(1), 105-112. Available at: https://ijer.ut.ac.ir/article 590.html.

51.Porter, M. E. (1991). Towards a dynamic theory of strategy. Strategic Management Journal, 12(S2), 95117. https://doi.org/10.1002/smj.4250121008.

52.Porter, M.E., \& Kramer, M.R. (2006). The link between competitive advantage and corporate social responsibility. Harvard Business Review, $84(12)$, 78-92. Available at: https://hbr.org/2006/12/strategy-andsociety-the-link-between-competitive-advantage-and-corporate-social-responsibility.

53.Porter, M.E., \& Kramer, M.R. (2011). The Big Idea: Creating Shared Value. How to reinvent capitalism and unleash a wave of innovation and growth. Harvard Business Review, 89(1-2). Available at: https://hbr.org/2011/01/the-big-idea-creating-shared-value.

54.Ruf, B.M., Muralidhar, K., Brown, R.M., Janney, J.J., \& Paul, K. (2001). An empirical investigation of the relationship between change in corporate social performance and financial performance: A stakeholder theory perspective. Journal of Business Ethics, 32(2), 143-156. https://doi.org/10.1023/A:1010786912118.

55.Shaukat, A., Qiu, Y., \& Trojanowski, G. (2016). Board attributes, corporate social responsibility strategy, and corporate environmental and social performance. Journal of Business Ethics, 135(3), 569-585. https://doi.org/10.1007/s10551-014-2460-9.

56.Taliento. M., Favino, C. Netti, A, (2019). Environmental, Social, and Governance Information Impact on Economic Performance: Evidence of a Corporate "Sustainability Advantage" from Europe. Sustainability, 11(6), 1-26, March. https://doi.org/10.3390/su11061738.

57.Van Beurden, P., \& Gössling, T. (2008). The worth of values-a literature review on the relation between corporate social and financial performance. Journal of Business Ethics, 82(2), 407-424. https://doi.org/10.1007/s10551-008-9894-x.

58.Van Duuren, E., Plantinga, A., Scholtens, B. (2016). ESG Integration and the Investment Management Process: Fundamental Investing Reinvented. Journal of Business Ethics, 138(3), 525-533. https://doi.org/10.1007/s10551-015-2610-8.

59.Waddock, S.A., \& Graves, S.B. (1997). The corporate social performance-financial performance link. Strategic Management Journal, 303-319. https://doi.org/10.1002/(SICI)10970266(199704)18:4\%3C303::AID-SMJ869\%3E3.0.CO;2-G.

60.Wang, H., Choi, J., \& Li, J. (2008). Too little or too much? Untangling the relationship between corporate philanthropy and firm financial performance. Organization Science, 19(1), 143-159. https://doi.org/10.1287/orsc.1070.0271.

61.Weber, M. (2008). The business case for corporate social responsibility: A company-level measurement approach for CSR. European Management Journal, 26(4), 247-261. https://doi.org/10.1016/j.emj.2008.01.006 